\title{
Services for Users with Disabilities in Joint Libraries in China
}

\author{
Xiaofen Zhao ${ }^{1}$, Li Lin $^{1} \&$ Yan Zhang ${ }^{1}$ \\ ${ }^{1}$ Qingdao University of Science and Technology Library, Qingdao, China \\ Correspondence: Yan Zhang, Qingdao University of Science and Technology Library, Qingdao 266061, China. \\ E-mail: zy@qust.edu.cn
}

Received: September 23, 2019

Accepted: October 4, 2019 Online Published: October 20, 2019

doi:10.5539/ass.v15n11p42

URL: https://doi.org/10.5539/ass.v15n11p42

\begin{abstract}
China has a large population with disabilities. In China, there may be varieties of barriers for disabled users to access library resources and services. Joint libraries are a new type of libraries constructed by local government and one or more colleges (universities), playing a dual role as both academic library and public library. Therefore, the users of joint libraries include not only college students and teachers, but also other people from all walks of life. Undoubtedly, the resources and services of these joint libraries must be provided for all kinds of users. Since 1997, more than ten joint libraries have been constructed and opened in China. In this article, we first briefly discussed the causes for the barriers to users with disabilities in libraries. Second, taking joint libraries as a case, we focused on the services to remove barriers and to ensure information equity for disabled people. Provision of equal services for disadvantaged groups is an essential indicator of joint libraries. The present article may provide recommendations for the future sustainable development of joint libraries in China and other developing counties.
\end{abstract}

Keywords: joint library, readers with disabilities, information equity, disadvantaged groups

\section{Introduction}

All people have the right of access to library services and resources to meet their demands for information, knowledge, education and recreation. The cultural and information needs of disabled persons are an essential element for current information society, and should be encouraged in all democratic countries. In recent years, information services for disabled readers have attracted more and more attention worldwide (Huang, 1990; Morgan, 2003; Qian \& Tu, 2004; Joint \& Beaton, 2005; Kerscher, 2006; Koulikourdi, 2008; Yoon et al., 2013; Bodaghi, Awang-Ngah, \& Abdullah, 2014). China has a large population with disabilities. At present, the statistics show there are approximately 82.96 million disabled people, who constitute an important group of China's population. However, due to diverse reasons, their mental health needs are generally ignored.

Libraries are the most important information exchange centers and should provide fair and equal services for all the people. Libraries are obliged to provide information for all kinds of users irrespective of their gender, age, race, political affiliation or disability (Babalola \& Haliso, 2011). Information equity is one of the basic principles and requirement for public libraries. As stated by UNESCO Public Library Manifesto (UNESCO, 1994): "The services of the public library are provided on the basis of equality of access for all...Specific services and materials must be provided for those users who cannot, for whatever reason, use the regular services and materials, for example linguistic minorities, people with disabilities or people in hospital or prison." Additionally, a growing number of young people with disabilities entering higher education, academic libraries should also consider their needs (Joint \& Pinder, 2005; Phukubje \& Ngoepe, 2017). At present, there are few libraries for disabled people in China. The resources and services for disabled population are far from enough in most libraries. People with disabilities are most in need of special care, support and help compared with healthy groups. Information rights and equity of disabled readers have become an important issue in all kinds of libraries in China.

In recent years, due to the advantages such as cost-saving and resource-sharing, libraries jointly financed and shared by one or more academic institutions (colleges or universities) and local governments have received wide attention in China (Table 1) (Sun \& Wang, 2011; Wang, 2012; Zhang, 2017). These libraries have dual functions of both academic library and public library, which reduce duplication of investment and save costs. However, their users also increased because they must open to both the public and readers from universities, and should 
provide convenient, efficient, high quality and satisfactory service to all kinds of readers (Wang \& Yan, 2003; Ye, 2011). Innovative co-operation model including management efficiency and service levels must be improved. Clearly, as one important aspect of the management and operation mode, substantial measures should be adopted to reduce information inequities for persons with disabilities.

In the present article, we briefly discussed various barriers for people with disabilities existing in common libraries in China. More importantly, we analyzed the effective measures to eliminate barriers for users with disabilities in joint libraries. Our aim is to provide recommendations for the future sustainable development of joint libraries between academic institutions and local governments in China and other developing counties.

Table 1. The joint libraries constructed by colleges and local governments in China

\begin{tabular}{ll}
\hline Library & Opening time \\
\hline Jinhua Polytechnic Library & 1997 \\
Liaocheng University Library & 2001 \\
Ningbo University Science and Technology Park Library & 2003 \\
Northeast Petroleum University Library & 2005 \\
Huanghuai University Library & 2005 \\
Chizhou College Library & 2005 \\
Sichuan Vocational and Technical College Library & 2007 \\
University Town of Shenzhen Library & 2007 \\
Jiyuan Vocational and Technical College Library & 2008 \\
Heyuan Vocational and Technical College Library & 2008 \\
Luoyang Science and Technology Library & 2013 \\
Ningbo Vocational and Technical College Library & 2014 \\
Hubei University of Arts and Science Library & 2016 \\
Shanxi Institute of International Trade \& Commerce Library & 2018 \\
Ya'an Vocational and Technical College Library & 2019 \\
Zhejiang Business Technology Institute Library & 2019 \\
\hline
\end{tabular}

\section{Barriers for People with Disabilities}

As one of the largest disadvantaged groups in China, people with disabilities generally cannot possess equal economic, political and social opportunities due to physical handicaps. Especially, they are generally at a disadvantage in education, economic income, competitiveness, career promotion, and social status. They tend to have lower levels of knowledge and fewer access to knowledge, and their demand for knowledge is often more urgent than the abled people. In addition, nowadays there are growing college students with disabilities. In China, there are about ten thousand students entering colleges or universities each year. They also need to access the resources and services of libraries to complete their studies (Joint \& Pinder, 2005; Phukubje \& Ngoepe, 2017).

Like other disadvantaged groups, disabled people encounter various barriers and difficulties in making use of libraries' resources. The common barriers are mainly summarized in following aspects.

\subsection{Physical Barriers}

Physical barriers for persons with disabilities are mainly due to insufficient barrier-free equipment and facilities. The planning, design and construction of libraries, including roads, reading room, toilets, book shelf, parking space, and other relevant facilities, should be convenient for the disabled to pass and use. Disabled people often have difficulty in traveling, particularly for them entering libraries with inadequate accessibility facilities. Unfortunately, at present, the majority of China's libraries lack a barrier-free environment. Physically handicapped people especially wheelchair users have great difficulty in using the facilities.

\subsection{Resource Barriers}

It's estimated that only $5 \%$ of the world's published output is made accessible in formats for people with print 
disabilities (Epp, 2006). Although some digital audio and textual products are available to people who can't use printed materials, most of them have no equal access to reading materials and other resources. In China, few specific library resources are developed for people with disabilities in most public libraries. For example, most libraries have no Braille books, talking books, and talking newspaper, which are representative resources for the visually impaired users. Meanwhile, assistive technologies were not available in libraries. These may be important reasons that blind and vision-impaired users are generally reluctant to go to the library.

\subsection{Technical Barriers}

In China, most disabled people have poor educational backgrounds, thereby leading them to lower ability to learn new techniques especially information techniques. Due to lack of knowledge and practical capacity, most users with disabilities have no skills to use the devices, equipment, facilities and information resources in libraries, further limiting their access to knowledge.

\subsection{Financial Barriers}

People with disabilities generally belong to low-income groups, who are not willing to afford transport fares and the cost of library and information services, such as printing, copying, and scanning. Most libraries do not open free for readers with disabilities, which is also one of the reasons for their unwillingness to go to the library.

\subsection{Psychological Barriers}

It is world-widely accepted that it's illegal to discriminate against people with disabilities. Many countries including China have made great efforts to achieve fairness and equality, however, discrimination against persons with disabilities actually exists more or less. Some disabled people often psychologically sensitive, lack of confidence, not willing to leave their homes and to make use of the library. If disabled readers can't be treated fairly by other readers, and especially librarians, they may feel uncomfortable when they are in libraries.

\section{Strategies to Eliminate Barriers for Persons with Disabilities}

\subsection{Establishing Accessible Libraries to Eliminate Physical Barriers}

The construction of accessible buildings and facilities is a prerequisite for a library to provide high-quality services for the disabled readers. The buildings and facilities must be equipped, staffed, and supplied adequately. However, the design, construction and maintenance of these facilities requires a lot of money. Library is a kind of public welfare, requiring public financial support. Both sides including the college and government must expand funding channels, and increase investment to build a library with accessible facilities to eliminate physical barriers for people with disabilities. The joint libraries are funded by both college and local government, which avoids repeated construction and makes full use of the funds. This is of great significance especially for economically undeveloped area.

Taking Luoyang Science and Technology (LST) Library as an example, it was a largest joint library with a total construction area of about $70,000 \mathrm{~m}^{2}$. LST Library was jointly constructed by Henan University of Science and Technology and Luoyang Municipal Government in 2013, with a total investment of about 50 million dollars. Its collections include 4 million volumes and 3000 serial titles, which are available to all readers from all walks of life in Luoyang, including college students, faculty and staff, and other readers from outside the university. It's a well-designed advanced library, and aims to provide high-quality services for all walks of readers as possible as it can. Evidently, if it were not jointly funded, the accessible resources and facilities may be not so advanced due to the insufficient money.

"Accessibility design" is a symbol of humanistic care for disabled people. The purpose of barrier-free design is to ensure special population, such as the people with disabilities, the elderly and other disadvantaged groups, to participate fully in social life equally. Considering the needs of disabled users, the design and construction of LST Library well met the standards of "Guides for design on accessibility of urban roads convenience disabled urban roads and buildings" (GB 50763-2012). LST library buildings have special routes for disabled users, and accessible entrances for wheelchair users. There are several reception rooms and reading rooms equipped with special seats for disabled readers. The rooms are specialized and comfortable. Its architectural design took into account various needs of people with disabilities from the perspective of ease of use, such as: (1) the rooms were set in the lower floors; (2) several elevators were equipped for readers; (3) specific furniture such as reading tables and chairs were designed for wheelchair users and other disabled people, some of which is adjustable to working height; and (4) it has special toilet facilities for the disabled users. All these facilities provide great convenience for the disabled users, reflecting the humane care of LST Library.

As abovementioned, the investments on joint library were mainly form local government and the college. In 
addition, there should be more channels to raise funds. The donation from community and individuals must be encouraged to make up for the shortage of funds. It is also necessary to seek the supports from social charity, disability foundation, enterprise, businessmen, and all walks of life.

Some users with disabilities can't come to the library due to their handicapped bodies or the long distance of their residence. Libraries can provide "book-to-door" service, delivering paper resources to their home, or sending electronic data via emails.

\subsection{Expanding Information Resources to Eliminate Resource Barriers}

Accessibility of libraries includes not only the accessibility to buildings, but also services, materials and programs. Disabled users have special needs for information resources and materials, which deserve special attention of a joint library. As educational institutions and information dissemination centers, libraries should guarantee all users, especially hearing- and speech-impaired people to utilize information resources, with equal opportunities to access information resources. Reading room should be equipped with computers with special software, projectors, audio-visual equipment for the blind, Braille books and audiobooks and reading aids, etc., allowing the users with disabilities to exchange and learn without barriers. The literatures such as recovery, employment, law, massage, and other aspects of mental health care for persons with disabilities, should be supplied to meet their information needs. In fact, the abled users can also benefit from the literature resources for the disabled people. This can bring not only direct benefits for the disabled users, but also indirect benefits for the whole society.

However, in this point of view, most libraries including LST Library still have insufficient information resources for disabled people. This needs the efforts of the whole society, including governments and the public, publishers, libraries and librarians, and the people with disabilities themselves.

\subsection{Strengthening Training and Guidance to Eliminate Technical Barriers}

Training for library users with disabilities can benefit them from using library resources (Riley, 2009). To remove technical barriers for people with disabilities, it is necessary to carry out a variety of training programs and seminars to help them understand the distribution of library resources, the use of devices, searching literatures, and the ability to use these resources. For their first time into the library, a detailed guide should be provided, such as touch screen devices, and technicians to answer their questions. Secondly, librarians and technicians should teach or help them to use the library technology and equipment, or organize special lectures on their technical guidance and training. The ultimate purposes are to enable them to know how to use various equipment, facilities, and resources in the libraries.

Knowledge assistance is defined to provide knowledge products or services for disadvantaged groups, free or at low cost, by the government and social organizations. Through supportive services, knowledge assistance can increase the knowledge of disadvantaged groups, and enhance their competitiveness and social participation, thus changing their disadvantaged status. The disabled people are groups in great demand of knowledge. Libraries should actively participate in knowledge assistance and provide knowledge services to the disabled population, attracting more disabled readers to enter the library and thereby maximizing social benefits of the library. In turn, the assistance can attract more attention of the government and society, helping the library get more funding and support to achieve healthy development.

Serving the society is considered one of the important functions of colleges. Joint libraries generally locate in colleges' campus, where many experts and scholars live and teach. The rich human resources can provide much more support for the implementation of knowledge and intellectual assistance, compared to other types of libraries. The libraries can invite college teachers to hold counseling, seminars and training for the disabled readers. College students are also the group with a high level of knowledge. They are potential volunteers who can be organized to carry out charity activities, such as teaching the disabled users to utilize library resources. In addition, the college can organize public welfare classes for the disabled readers, teaching courses they are interested in, such as illness and health, career and employment, law and policy.

\subsection{Open Free to Eliminate Economic Barriers}

As nonprofit cultural organizations, joint libraries should reform their management and operation modes to achieve free admission and services for readers with disabilities, to reduce their financial burden and eliminate economic barriers. The disabled population are generally of low income. If the cost of the resources and services is too expensive, which may prevent disabled people from entering libraries. All the resources and services of joint libraries should be provided free of charge to those people with disabilities, without any restriction. For example, LST Library open free to not only the students of the university, but also the residents in Luoyang. 
These measures encourage disabled people to go out of their home and into libraries.

\subsection{Improving Service Quality to Eliminate Psychological Barriers}

Disabled readers are a special group, who are generally psychologically sensitive and pessimistic, and disunited from society, lacking self-confidence and happiness. From the point of view of service, libraries should implement a principle of "readers-oriented, service first". Users with disabilities should obtain respect and care from librarians and other readers, which can help them to overcome psychological barriers. It is important to create a friendly and comfortable environment for them.

Services for the disabled users should be balanced at an appropriate "degree". The best services are they can feel respect and equality, but not excessive care and attention. Library staff can provide necessary helps, such as fetching and carrying books, if the disabled users need. However, too much care and different services may make them uneasy and anxious, which may deter the users with disabilities from using the possible services. This requires librarians to fully recognize psychological needs of the disabled users, and thus to improve their service levels. Don't be superior or compassionate when communicate with them. Librarians from joint libraries are a group with high academic and education backgrounds. They are friendly, kind-hearted, and helpful to users from all walks of life, particularly to the disabled needing additional cares.

Furthermore, to provide the best services for library users with disabilities, library staff, specifically the new staff, and front-line staff who are usually first to contact with disabled users, should receive disability awareness training (Charles \& Joint, 2005). Thereby, the staff will know, for example, how to help wheelchair users, how to communicate with hearing-impaired users, what to do for visually impaired people, or perhaps just what colors of paper might be more suitable for dyslexic readers. The main task to organize disability awareness training is to bear the service principle in mind "Person first, disability second", which should be implemented in joint libraries. Based on this principle, guidelines on library service standards for people with disabilities may be developed.

\section{Conclusion}

According to Maslow's theory "hierarchy of needs", all humankind need "physiological", "safety", "belonging and love", "social needs" or "esteem", and "self-actualization" (Maslow, 1943). Without exception, the disability community also have such needs, including knowledge. The disabled groups have the right to share the achievements of human civilization. They need to learn more knowledge to improve their lives. In modern China, the society should have the ability and obligation to help disadvantaged groups, to achieve social fairness and justice. Joint libraries have a dual role as both academic library and public library. Providing fair and equal services for people with disabilities (as well as other disadvantaged groups) is a manifestation of humanized management and services of a library. As a type of new library jointly constructed by colleges and governments, joint libraries should take effective measures to eliminate the barriers and make their contribution to the development of harmonious society.

\section{Acknowledgements}

This work was supported by Qingdao Philosophy and Social Sciences Planning Project (QDSKL1901223), Humanities and Social Sciences Research Project of Qingdao University of Science and Technology (18XB25), Shandong Social Sciences Planning Research Project (18CRCJ05), and Shandong Soft Science Planning Project (2018RKB01342).

\section{References}

Babalola, Y. T., \& Haliso, Y. (2011). Library and information services to the visually impaired-the role of $\begin{array}{llllll}\text { academic libraries. } & \text { Canadian } & \text { Social } & \text { Science, } & 7, & 140-147 .\end{array}$ https://doi.org/10.3968/j.css.1923669720110701.015

Bodaghi, N. B., Awang-Ngah, Z. B., \& Abdullah, N. (2014). Student volunteers as academic saviours and social connectors among the visually impaired in an academic library. Libri, 64, 40-48. https://doi.org/10.1515/libri-2014-0004

Charles, S., \& Joint, N. (2005). Person first, disability second: Disability awareness training in libraries. Library Review, 54, 453-458. https://doi.org/10.1108/00242530510619147

Epp, M. A. (2006). Closing the 95 percent gap: Library resource sharing for people with print disabilities. Library Trends, 54, 411-429. https://doi.org/10.1353/lib.2006.0025

Huang, S. T. (1990). Reference services for disabled individuals in academic libraries. The Reference Librarian, 11, 527-539. https://doi.org/10.1300/J120v11n25_26 
Joint, N., \& Beaton, M. (2005). Glasgow city council: Library, information and learning services for disabled people in Glasgow. Library Review, 54, 472-478. https://doi.org/10.1108/00242530510619174

Joint, N., \& Pinder, C. (2005). Customers with disabilities: The academic library response. Library Review, 54, 464-471. https://doi.org/10.1108/00242530510619165

Kerscher, G. (2006). The essential role of libraries serving persons who are blind and print disabled in the information age. In Computers Helping People with Special Needs (pp. 100-105). Springer. https://doi.org/10.1007/11788713_16

Koulikourdi, A. (2008). Library services for people with disabilities in Greece. Library Review, 57, 138-148. https://doi.org/10.1108/00242530810854017

Maslow, A. H. (1943). A theory of human motivation. Psychological Review, 50, 370-396. https://doi.org/10.1037/h0054346

Morgan, G. (2003). A word in your ear: Library services for print disabled readers in the digital age. The Electronic Library, 21, 234-239. https://doi.org/10.1108/02640470310480489

Phukubje, J., \& Ngoepe, M. (2017). Convenience and accessibility of library services to students with disabilities at the University of Limpopo in South Africa. Journal of Librarianship and Information Science, 49, 180-190. https://doi.org/10.1177/0961000616654959

Qian, G., \& Tu, Y. (2004). Research on the disability-free issues in the library website development. Journal of Academic Libraries, 22, 56-59. https://doi.org/10.3969/j.issn.1002-1027.2004.05.016

Riley, C. (2009). Training for library patrons who are hard of hearing. Journal of Access Services, 6, 72-97. https://doi.org/10.1080/15367960802286260

Sun, H., \& Wang, X. (2011). Review on co-construction between the university libraries and the public libraries in China. Research on Library Science, 10, 6-9. https://doi.org/10.15941/j.cnki.issn1001-0424.2011.10.004

UNESCO. (1994). IFLA/UNESCO Public Library Manifesto 1994. Retrieved from https://www.ifla.org/publications/iflaunesco-public-library-manifesto-1994

Wang, J., \& Yan, W. (2003). A new model of library management: An overview of the Ningbo Higher Education $\begin{array}{llllll}\text { Zone Library. Journal of Academic } & \text { Libraries, } & 21, & 70-71 .\end{array}$ https://doi.org/10.3969/j.issn.1002-1027.2003.02.016

Wang, X. (2012). Practice and research review on co-construction library of university and public in China. Library Work and Research, 5, 26-29. https://doi.org/10.16384/j.cnki.lwas.2012.05.008

Ye, M. (2011). Operation mode of cooperative development library. Research on Library Science, 17, 31-33. https://doi.org/10.15941/j.cnki.issn1001-0424.2011.17.014

Yoon, K., Newberry, T., Hulscher, L., \& Dols, R. (2013). Call for library websites with a separate information architecture for visually impaired users. Proceedings of the American Society for Information Science and Technology, 50, 1-3. https://doi.org/10.1002/meet.14505001100

Zhang, J. (2017). A study on the management mechanism of China's co-construction of university and public library. Journal of Academic Libraries, 35, 14-19. https://doi.org/10.16603/j.issn1002-1027.2017.02.002

\section{Copyrights}

Copyright for this article is retained by the author(s), with first publication rights granted to the journal.

This is an open-access article distributed under the terms and conditions of the Creative Commons Attribution license (http://creativecommons.org/licenses/by/4.0/). 